\title{
L2 acquisition of temporality: Findings from a corpus based study of the grammatical encoding of past time
}

\author{
Ann-Kristin Helland Gujord* \\ University of Bergen
}

\begin{abstract}
The article presents a study that investigates the role of verb semantics (the Aspect Hypothesis) and L1 influence in texts from a learner corpus (Norsk andrespråkskorpus, ASK) that were written by 73 Vietnamese and 88 Somali learners of Norwegian. The main structures addressed are the preterite and the present perfect. There are two key findings. First, the Aspect hypothesis is not corroborated because lexical-aspectual influence is not detected. Second, the learner's L1 is found to affect the acquisition process. The detected L1 effects agree with previous studies documenting that the learner's L1 can affect the acquisition of temporal morphology and, moreover, that the perfect category in many cases is involved. Although the lack of support for the Aspect Hypothesis can partially be explained in terms of data type, it is suggested that the findings point to the importance of testing the hypothesis on other types of data besides those usually exploited.
\end{abstract}

Key words: L2 acquisition of temporal morphology, the Aspect Hypothesis, L1 influence, Norwegian learner corpus (ASK).

\section{* Principle contact:}

Ann-Kristin Helland Gujord, Associate Professor

Faculty of Humanities, University of Bergen, Norway

Tel.: +4755 582457

E-mail: Ann-Kristin.Gujord@uib.no

Bergen Language and Linguistic Studies (BeLLS), May 20th 2015. (C) Gujord DOI: $10.15845 /$ bells.v6i0

This is an Open Access article distributed under the terms of the Creative Commons Attribution License (http://creativecommons.org/licenses/by/3.0/). 


\section{Introduction}

This paper presents a study in which L2 acquisition of past morphology is explored from two different theoretical positions. One theoretical position emphasizes the universal, common path of L2 acquisition of tense and aspect morphology, while the other position stresses the importance of influence from previously acquired languages. The former perspective, the universalistic, relates to the role of verb semantics as described in the Aspect Hypothesis (Andersen and Shirai 1994, Bardovi-Harlig 2000, Shirai 2009). The core prediction in the Aspect Hypothesis is that L1 and L2 learners make associations between grammatical markers of tense and aspect and lexical-aspectual categories (Collins 2004, 253). In particular, the present study examines whether the predictions concerning the role of telicity in the acquisition of past morphology hold for the present L2 data. The language-specific perspective builds on findings from previous studies of L2 Norwegian (i.e. Tenfjord 1997, Gujord in press) and L2 English data (i.e. Collins 2002, 2004; Polunenko 2004) suggesting that L2 acquisition of past morphology, when certain L1-L2 relations exist, seems to involve L1 influence and, moreover, that the perfect category in many cases is involved. These studies challenge the traditional view that the area of morphology is more impervious than other subsystems of language to crosslinguistic influence (Jarvis and Odlin 2000, 536), as well as previous claims that studies of temporality as a whole show that a learner's L1 does not play an important role in L2 acquisition of tense and aspect (e.g. Bardovi-Harlig 2000, Dietrich, Klein and Noyau 1995). The corpus material used in the study consists of texts extracted from an electronic learner corpus of Norwegian $\left(\mathrm{ASK}^{1}\right)$. The texts were written by Vietnamese $(\mathrm{N}=73)$ and Somali $(\mathrm{N}=88)$ learners of Norwegian. The two main structures that are analysed in the learner texts are the preterite and the present perfect, the two categories in Norwegian through which the notion of past is coded. The following two research questions are investigated using the Norwegian L2 data.

1. Does the learners' use of the preterite and present perfect in Norwegian agree with earlier findings that support the Aspect Hypothesis?

2. Do the Vietnamese and the Somali learners display L1-specific patterns in their use of the present perfect and preterite in Norwegian?

The theoretical background for the research questions and their specific hypotheses is presented in Section 2. This section starts by presenting central terms, as well as Vendler's lexical-aspectual classification system, which is the analytical framework that has been adopted in research on the Aspect Hypothesis. The section continues with an introduction to the Aspect Hypothesis research and a survey of previous transfer research relevant for the present study. Section 3 accounts for the contrastive relations between the languages in question. Section 4 presents the current study and starts by stating the specific hypotheses. Then the corpus data used in the study are presented, along with a description of the analysis procedures. Section 5 presents the results of the analyses, which are discussed with respect to the research questions in section 6 . Section 7 closes with concluding remarks.

\section{Theoretical background}

2.1 Tense, aspect and Vendler's lexical-aspectual classification

Whereas tense is well established in the literature as a grammatical category expressing "location in time" (Comrie 1985, 9), the term "aspect" is used in several different ways. In the

\footnotetext{
${ }^{1}$ ASK is an abbreviation of $\underline{A} n d r e \underline{S p r a ̊ k s} \underline{K}$ orpus, meaning Second Language Corpus in Norwegian.
} 
current study, aspect refers to a non-deictic category which expresses different types of temporal perspectives that focus on different parts of the situation, such as the beginning of a situation or the completeness of a situation, and so forth. Lexical aspect is defined as a lexical-semantic category that refers to properties of the situation as described in the verb phrase and sometimes the whole sentence. In order to make the current study comparable to previous studies, the framework that has been adopted for the analysis of lexical-aspectual properties of verb phrases is Vendler's (1967). The Vendlerian classes are primarily distinguishable by two semantic features, that is, whether or not the situation described by the verb phrase is ongoing ( \pm dynamic), and whether or not the situation described includes an inherent endpoint or ends in a clear result or goal $( \pm \text { telic })^{2}$. Vendler's states are non-dynamic situations that continue without changing, such as 'to know something'. Activities also continue without changing, but are dynamic situations that require energy to keep going, as with 'run'. Activities do not involve a natural endpoint, goal or result: they are atelic situations. Accomplishments are dynamic and durative situations, and contrast with activities in that they are telic. That is, 'walk in the park' is an activity, while 'walk to the park' is an accomplishment because the phrase includes an endpoint. Finally, achievements, like accomplishments, are dynamic and telic, but unlike accomplishments, achievements are punctual and refer to a momentary change of state, such as 'recognise' and 'begin'.

\subsection{The universalistic perspective: The Aspect Hypothesis}

The Aspect Hypothesis refers to the observation that learners make associations between grammatical markers of tense and aspect and lexical-aspectual categories. Language learners do not apply tense and aspect morphology in all contexts; the distribution is influenced by lexical-aspectual properties of verb phrases. This semantic bias is observed in both initial and later stages of morphological acquisition (Bardovi-Harlig 2000, 272; Ayoun and Salaberry 2008, 583). The Aspect Hypothesis has been extensively investigated in the field since the 1980s, and there is great uniformity in the findings that support its predictions. According to Odlin, studies investigating the Aspect Hypothesis have shown "an impressive if not total consistency in studies of learners of many different language backgrounds" (Odlin 2005, 12). Furthermore, Ortega $(2009,127)$ refers to the hypothesis as "well-established fact". While the Aspect Hypothesis has been applied to different contexts, its prediction for L2 acquisition of past time marking has received the most solid empirical support and has proved to be a robust finding (Bardovi-Harlig 2000, 233; Collins 2002, 47). The prediction is that learners will first use inflection of past forms with verb phrases that express an instantaneous change of state and a clear end result (Shirai 2009, 172). In other words, past morphology is predicted to spread from telic verb phrases to atelic verb phrases, so that verbs in phrases like 'I read this novel last summer' are more likely to be coded for past than verbs in phrases such as 'I enjoyed reading novels last summer'. Furthermore, inherent in the Aspect Hypothesis is also the claim that the use of morphology expands from achievement - accomplishment - activity - state.

Within the Aspect Hypothesis framework, influence from lexical aspect is acknowledged as a universal in the acquisition process. Consequently, the learner's L1 is not given any particular weight or studied systematically (Odlin 2005; Collins 2004; Shirai 2009;

\footnotetext{
${ }^{2}$ Most of the L2 studies in research on the Aspect Hypothesis have based their analyses of semantic aspect on Andersen's (1991) reworking of the Vendlerian classes (Bardovi-Harlig 2000, 219, Collins 2002, 45). Aside from the features $( \pm$ dynamic) and ( \pm telic), which Vendler also emphasises, Andersen adds the punctual - nonpunctual distinction ( \pm punctual).
} 
Sharma and Deo 2009). According to Collins, this has to do with the purpose of the study of the Aspect Hypothesis because "Divergent patterns of acquisition as a function of L1 background would challenge the universal status of the semantic category" (Collins 2004, 252). However, the potential effect of $L 1$ influence has recently been given more attention, for instance, by Shirai (2009) and Chan et al. (2012). Shirai openly states that "results from previous L2 research that supported the Aspect Hypothesis can also be partially attributed to L1 influence" (2009, 184). Moreover, some insight into L1 influence within this framework has already been gained. A few studies conducted within Aspect Hypothesis research have found that the learner's L1 affects the acquisition of tense and aspect. For instance, in two studies Collins $(2002,2004)$ found that Francophone learners of English overused the present perfect in preterite contexts. Although the distribution of past forms was consistent with the predictions of the Aspect Hypothesis, the distribution of the present perfect showed an L1specific pattern that has not been documented in similar studies of learners from other L1 backgrounds (Jarvis and Pavlenko 2008, 95). In telic verb phrases, the learners used the present perfect in contexts where a target-like use would require the simple past in English (Collins 2002, 83). Collins attributes this finding to the passé composé (= periphrastic past) in French, which is equivalent in form, but not function, to the English present perfect. The same tendency was found in a study of French-speaking learners of English living in France, conducted by Ayoun and Salaberry (2008). Although there are some findings in research on the Aspect Hypothesis that suggest that the L1 has an effect on the acquisition of tense-aspect morphology, and that there probably is an interaction between lexical aspect and L1 influence (Collins 2002, 2004, Izquierdo and Collins 2008), the main conclusion in these studies is that learners' L1s do not change the sequence of emergence, but may have an impact on the magnitude of the effect of lexical aspect (e.g. Collins 2004, 257). This is also in line with one of the conclusions Bardovi-Harlig (2000) draws in her extensive survey of research on temporality in an L2. According to her, all in all, the studies she surveys do not reveal a "significant L1 effect" on the acquisition process (Bardovi-Harlig 2000, 411). The acquisition of tense and aspect is first and foremost developmentally constrained, and lexical aspect is one of the most important factors in this respect.

\subsection{The language-specific perspective: The role of the L1}

Apparently, then, L1 influence has a minor role in the acquisition of tense-aspect morphology, at least based on what the vast majority of research has been able to reveal so far. Scholars such as Jarvis and Pavlenko $(2008,61,92)$, however, claim that this contention is related to methodology as well as to a lack of understanding of how L1 effects can be manifested in interlanguages, and not because the L1 fails to operate in the L2 acquisition of temporal morphology. Jarvis and Pavlenko (2008) are contributors to transfer research, and Collins's study, surveyed above, is mentioned in their survey of transfer in the domain of temporality. Another study mentioned by Jarvis and Pavlenko, which is relevant to the current study, is Polunenko (2004). She observed that Russian L2 learners overuse the present perfect in English because they make associations between the perfective aspect in their Russian L1 and the English present perfect. Again, the present perfect is involved in a study in which an L1specific pattern is observed in L2 acquisition of temporal morphology. This is important because the same pattern is observed in several studies of L2 Norwegian. Contrary to the international field of SLA, L1 influence has indeed been an important issue in many studies of how L2 learners acquire temporality in Norwegian (Gujord in press). The most important finding in this research for the present discussion is the demonstration of transfer effects in the acquisition and use of the present perfect category. For instance, in a longitudinal case 
study of four Vietnamese learners of Norwegian, Tenfjord (1997) found that the Vietnamese learners acquired the present perfect before the preterite, a finding she interpreted as a facilitating effect of influence from Vietnamese $(1997,237)$. This study led up to several cross-sectional transfer studies of written Norwegian interlanguage data, which focused specifically on the present perfect category. For instance, and similar to Collins, Karrer (1999) observed that German learners had problems with the perfect-preterite distinction in Norwegian. The German present perfect and Norwegian present perfect are similar in form but not in function, and according to Karrer, the German learners transferred the functions of the perfect category from their L1 to the L2. Functional transfer was also detected in Randen (1999), who found that Russian learners use the perfect in Norwegian predominantly to express terminated actions. Her interpretation agrees with Polunenko (2004): the Russian learners make associations between the perfective aspect in their L1 and the present perfect in the L2. Moskvil (2004) and Helland (2005) examined Turkish and Vietnamese learners' use of the preterite and the perfect in Norwegian. Moskvil compared the distribution she found in the Turkish texts to the distribution from a control group of texts produced under the same conditions by Vietnamese learners. Helland (2005) conducted a similar study, but used texts from Vietnamese learners as the primary material and texts written by Turkish learners as the control. Both studies found that the Turkish learners, who lack a perfect category in their L1, displayed a stronger tendency for non-nativelike use of the present perfect in preterite contexts when compared to the Vietnamese learners. In a similar vein, Janik (2010) investigated transfer in Polish learners' use of the present perfect and the preterite in Norwegian. A perfect category does not exist in Polish, and Janik found that the Polish learners had more problems distinguishing the preterite from the perfect in Norwegian as compared to learners whose L1s have a perfect category similar to the Norwegian one. The studies of L2 Norwegian and L2 English surveyed in this section demonstrate that a learner's L1 can affect the acquisition of tense and aspect morphology, but also to the fact that the perfect category in many cases is subject to influence from the tense and aspect system in the learner's L1 in.

\section{Contrastive relations}

In order to encode past time in Norwegian in a target-like manner, learners have to figure out the appropriate contexts for two forms: the preterite and the perfect. The preterite encodes reference to the past. It is inflectional and realized by the suffix -et on regular verbs:

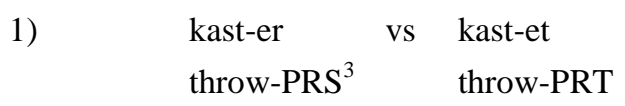

Whereas the preterite simply expresses that a situation took place at a definite time point, or period of time, in the past, the Norwegian present perfect prototypically codes reference to a present state resulting from a past event. ${ }^{4}$ It is a periphrastic construction and consists of the auxiliary have and the participle of the main verb: ${ }^{5}$

$\begin{array}{llllll}\text { 2) Jeg } & \text { ha-r } & \text { les-t } & \text { denne } & \text { boken } & \text { før } \\ \text { I } & \text { have-PRS AUX } & \text { read-PST PTCP } & \text { this } & \text { book } & \text { before }\end{array}$

\footnotetext{
${ }^{3}$ See appendix

${ }^{4}$ Corresponds to Comrie's (1976) 'perfect of result'.

${ }^{5}$ In Norwegian, it is also possible to form a perfect construction with the copula 'være' ('be') if the main verb is intransitive and denotes a change or development (Hagen 1998, 293).
} 
The prototypical perfect in Norwegian perfect is a "true" perfect (Dahl 1985, 62) in the sense that it cannot under any circumstances be used in combination with definite time reference. The distribution pattern of the preterite and the present perfect in Norwegian largely aligns with that of English (Elsness 2001, 32). The present perfect in Norwegian, as in English, has not undergone the development observed in German and spoken French, where the perfect can be combined with specific reference to the past (Lindstedt 2000, 371). Yet, the Norwegian perfect has developed other additional functions. For instance, the perfect in Norwegian can be used to express that an action that started in the past still holds (3) (Comrie's 'perfect of persistent situation'), that a situation took place in the immediate past (4) (Comrie's 'perfect of recent past'), as well as inferential evidential information (5):

$$
\begin{array}{lllllll}
\text { 3) Jeg } & \text { ha-r } & \text { bo-dd } & \text { syv } & \text { år } & \text { i } & \text { Bergen } \\
\text { I } & \text { have-PRS AUX } & \text { live- PST PTCP } & \text { seven } & \text { years } & \text { in } & \text { Bergen }
\end{array}
$$

4) Jeg ha-r ikke sov-et

I have-PRS AUX not sleep- PST PTCP well tonight
5) Tyven ha-r komm-et inn gjennom dette vinduet (inference based on observation) the thief have-PRS AUX come-PST PTCP in through this window

Somali and Vietnamese, the two L1s in the current study, are both very different from the Norwegian language, but they are distinguished from Norwegian in quite different ways. Although Somali is a highly synthetic language with rich verb morphology, the semantic distinction that exists between the preterite and the present perfect in Norwegian is not encoded in Somali because a perfect category does not exist. In contrast, Vietnamese is an isolating language without inflection. Vietnamese verbs are tenseless, and temporal reference is not marked linguistically because it is accessible through the basic time of the contexts; the basic time is "the time which has been made clear in the context up to that point" (Thompson 1965, 209). An important question is how contexts for the preterite and the present perfect in Norwegian are coded in Vietnamese and Somali. In order to answer this question empirically, information about the encoding of past time in the learners' L1s was collected by means of a translation questionnaire method. More precisely, I used a questionnaire developed by Dahl (1985) and Lindstedt (2000). Native speakers of Vietnamese and Somali translated the perfect questionnaire, which consists of 151 sentences in English from 88 contexts intended to collect information about the perfect category and related categories. It is oriented towards semantic content and function and is based on universal features of crosslinguistic categories expressing concepts all natural languages are presumably able to express, such as completed situations in the past. Hence, it provides the opportunity to observe how the same meaning is conveyed in different languages. The most important findings from this contrastive analysis are summarised below.

In Somali, there are three different categories that encode the notion of 'pastness' (Saeed 1993): past simple, past progressive, and past habitual, and analyses of translated sentences show that the past simple in Somali is, in the majority of cases, used in contexts where Norwegian native speakers use the present perfect. At the same time, based on the translation data, I would argue that the Vietnamese learners, in contrast to the Somali learners, do have a semantic distinction in their L1 that corresponds to the one that exists between the 
preterite and perfect in Norwegian (see Tenfjord 1997). Although it is not obligatory to mark temporal reference, in cases where the situation refers to "time different from this basic time" (Thompson 1965, 209), particular time markers must be used in order to clarify the temporal frame. Of these time markers, the markers 'đã' and 'rôi' express past time. The contrastive analysis in the present study shows that although contexts for the preterite in Norwegian are not marked by a time marker in Vietnamese, in most Vietnamese translations of contexts with the present perfect in Norwegian, 'đã' or 'rôi', or both, appear.

The translations of the sentences in bold (provided with context) in (6) and (7) exemplify the L1-L2 relations. Whereas sentences in Norwegian that require the preterite (6a) are usually not marked by linguistic devices in Vietnamese (6b), these sentences are expressed in Somali with the general past to convey the same meaning (6c). However, the same Somali general past form, as in sentence (7a), is also used in contexts in which a Norwegian present perfect form appears (7b) because Somali does not encode the semantics inherent in the Norwegian present perfect. On the other hand, whereas sentences with a preterite in Norwegian remain unmarked in a Vietnamese translation, sentences with a Norwegian perfect must usually be rendered by means of 'đã' or 'rôi' $(7 \mathrm{c})^{6}$.

6) [A question asked at 9 o' clock A.M.: Why do you look so tired?]

Answer: I WAKE up at 4 o' clock this morning (or: today).

6a) Norwegian: Jeg våkn-et klokken fire i dag

I wake-PRT 4 o' clock today

6b) Vietnamese: Tôi thức dậy lúc 4 giờ sáng này

I wake up when 4 o' clock morning this

6c) Somali:

$$
\begin{aligned}
& \text { Anigu waxaan toos-ay 4. tii habeenimo } \\
& \text { I DM wake-PST simple } 4 \text { o' clock night }
\end{aligned}
$$

7) [A: It seems that your sister never finishes books.]

B: (That is not quite true.) She READ this book (= all of it).

7a) Somali: Haa, iyadu way akhrid-ay buugan

yes she DECL marker read-PST simple book

7b) Norwegian: Ja hun ha-r les-t denne boken

yes she has-PRS AUX read- PST PTCP this book

7c) Vietnamese: Vâng có chị ây đã đọc quyển sách này yes exist sister that TM read CLF book this

\footnotetext{
${ }^{6}$ These translations are taken from the translations of the perfect questionnaire. A more detailed analysis of the translation data is available in Gujord in press.
} 


\section{The present study}

\subsection{Hypotheses}

In order to address the general research questions of whether the learners' use of the past forms in Norwegian support the Aspect Hypothesis, and whether Vietnamese and Somali learners display L1-specific patterns in their use of the present perfect and preterite in Norwegian, two hypotheses were formulated.

1. Following the Aspect Hypothesis, it is expected that the Vietnamese-speaking and Somali-speaking learners will have a higher proportion of verb types in telic verb phrases (achievements and accomplishments) in the past than in atelic verb phrases (states and activities). This pattern is expected to appear in both correctly and incorrectly encoded phrases.

2. Based on previous findings and given the L1-L2 contrastive relations involved, it is expected that the Somali-speaking learners will have a higher rate of incorrect use of the preterite in contexts where Norwegian requires the present perfect, and a higher rate of incorrect use of the present perfect in preterite contexts, than will the Vietnamesespeaking learners.

\subsection{Corpus and participants}

The corpus material used in the study consists of texts extracted from an electronic learner corpus of Norwegian (ASK) containing 1700 texts (1.1 million tokens) written as responses to two different official tests of Norwegian for adult immigrants: Språkprøven i norsk for voksne innvandrere ('Language test for adult immigrants, intermediate level') and Test $i$ norsk høyere nivå ('Test of Norwegian - advanced level'). The corpus includes interlanguage data from $10 \mathrm{~L}^{7}{ }^{7}$ which represent a typologically diverse group of languages. The textual data in ASK are tagged for grammatical information, both using an automatic tagger for standard Norwegian (the Oslo-Bergen tagger), and manually by several coders with knowledge of second language acquisition (Tenfjord, Meurer and Hofland 2006). Moreover, ASK is error tagged for various types of deviations from the native language norm. For instance, the error $F$, which is of particular interest for the current study, indicates a "deviant selection of morphosyntactic category" (Tenfjord, Meurer and Hofland 2006, 1822), as shown in the example (8). In this sentence, the preterite ("gikk") is incorrectly used instead of the present tense ("går):

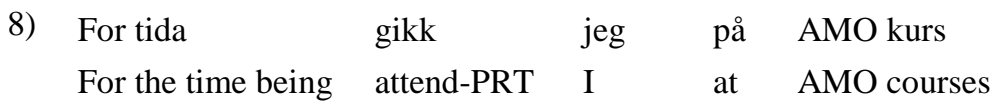

In addition to the textual data, the test takers completed a form on the same day as the test, providing personal information that may be related to the acquisition of a second language. Finally, the texts from seven of the L1s have been assessed following the Common European Framework of Reference for Languages, CEFR (Carlsen 2012).

The texts extracted in the current study are responses to the test measuring language at an intermediate level. The test takers were asked to write a short text on a given topic that related to a personal experience, required a description of an event, or asked for a viewpoint on a

\footnotetext{
${ }^{7}$ Albanian, Bosnian-Croatian-Serbian, Dutch, English, German, Polish, Russian, Somali, Spanish and Vietnamese. Each L1 is represented by 100 texts at each level, except for Vietnamese and Somali, for which texts exist only at the intermediate level.
} 
subject of general public interest (e.g. smoking, upbringing, equality of the sexes, etc.). The test takers were allowed to choose between several different prompts, and thus their topics varied significantly. Of the 161 total texts, 73 were written by native speakers of Vietnamese, and 88 by native speakers of Somali. Although the texts count among those classified according to the CEFR, this level placement is not taken into account here because the CEFR level does not influence the results presented in this article (Gujord 2013, 172).

\subsection{Method}

\subsubsection{Coding procedures}

In order to analyse lexical-aspectual influence and L1 influence on the uses of past morphology in L2 Norwegian, the clauses in the texts were analysed and coded for inflectional information and lexical-aspectual information as described below.

The first step in the analysis encompassed the identification of the temporal contexts in the clauses from the individual texts, which can be of the following types: present context, preterite context or perfect context. The type of temporal context expressed in the clauses were identified based on internal properties of the clause, but also through contextual inference from the parts of the discourse in which the clause occurs. Example (9) show a context identified as a preterite context by means of time expressions denoting definite time reference:

9) Jeg ha-r flytt-et mange ganger da jeg bo-dde i PLACE I have-PRS AUX have- PST PTC many times when.ADV I live-PRT in PLACE

Example (10) shows that sometimes definite time reference was inferred from the surrounding context, because a definite time reference was established in a narrative frame:

10) [a person writing about last year's summer vacation]

$\begin{array}{llllllll}\text { Vi } & \text { stopp-et } & \text { litt } & \text { der } & \text { og } & \text { tok } & \text { mange } & \text { bilder } \\ \text { we } & \text { stop-PRT } & \text { a bit } & \text { there } & \text { and } & \text { take.PRT } & \text { many } & \text { pictures }\end{array}$

In principle, what the context analysis generates is the identification of obligatory contexts for use of temporal morphology in Norwegian. Whereas it was fairly easy to identify the obligatory contexts for the preterite, the identification of contexts for the present perfect were more challenging. Furthermore, the term "obligatory context" is problematic with the perfect category. The preterite, as opposed to the perfect, are semantically redundant; the preterite endings (as well as present tense endings) on verbs are anaphoric because they simply refer to a point of reference already established in the context by means of adverbials as well as by being anchored in the discourse universe (see also Bardovi-Harlig 2000, Chapter 3 and Tenford 1997, 158). Accordingly, obligatory contexts can be identified. This is not case with the perfect. This category is not redundant per se, and the content expressed through the present perfect form can only come about by using it. The perfect expresses a temporal relation which is not easily inferred because there are no obligatory contexts for when to apply it. There exists only an intention to communicate what the present perfect encodes in Norwegian, for instance, to describe a present state as a result of a past incident. Hence, the identification of contexts for the present perfect lies primarily in the analysis of the discourse, which reveals the content that the informant wants to express in the clause. For instance, the 
contexts below are classified as present perfect contexts because they refer to past events or conditions which are finished: the reading of the book is finished (11), and the escape is over (12). ${ }^{8}$

11) Jeg ha-r en bok som het-er Sinddbads verden

I have-PRS AUX read- PST PTCP a book which be call-PRS Sinddbad's world

12) Jeg er en av dem som ha-r på flukt

I be.PRS one of those who have-PRS AUX travel- PST PTCP on escape

In sum, the context analysis of the clauses in the 161 texts generated 1934 obligatory contexts for the preterite and 235 obligatory contexts for present perfect.

Next, the learners' morphological marking of the temporal content in the clauses was analysed. These grammatically encoded clauses were coded as either present, preterite, present perfect, or past perfect depending on which of these forms occur in the clauses. Furthermore, clauses were coded as correct if the temporal morphological form used in a clause (preterite or present perfect) encoded the identified past context. In cases with no correspondence between the past context identified in the clause (e.g. a preterite context), and the temporal morphological form that occurs in the clause (e.g. a present tense form), the clause was coded as incorrect encoding, and the type of error distribution was registered. The analysis of the grammatical encoding in the clauses generated 1712 correct uses and 222 incorrect uses of the preterite, and 178 correct uses and 57 incorrect uses of the present perfect.

At the level of semantics, lexical-aspectual properties in clauses that contain verb forms inflected for the preterite and the present perfect were analysed based on Vendler's classification system as presented in section 2.1. The prediction in the Aspect Hypothesis applies to both preterite morphology and present perfect morphology, and in this analysis the preterite and present perfect were collapsed into one category of past morphology. This is because the frequency of present perfect verb phrases is much lower than that of preterite verb phrases, which makes it complicated to compare the forms, and to analyse the present perfect in the four Vendlerian classes. However, treating the present perfect category as merely a past category is not satisfactory. For that reason, despite the problematic aspect of comparing frequencies of such different magnitudes, in Gujord (2013, 276) I conduct the same analysis for the two past forms separately, and find that they display the same pattern separately as when they are analysed together. Accordingly, each clause with a preterite or a present perfect form was coded as denoting an achievement, accomplishment, activity, or state in accordance with the coding procedures applied in the current study. This is important because often the procedures for coding the data are not stated clearly in research on the Aspect Hypothesis. Moreover, verb phrases can be classified into several categories according to the context, which makes it particularly challenging to classify verbs into distinct classes of lexical aspect. In several studies, we do not know exactly which types of contexts generated which types of lexical-aspectual encoding. Shirai is one of the few researchers that has pointed out this situation, which he describes as not "ideal" for the purpose of ensuring replicability and comparability in Aspect Hypothesis research (Shirai 2013, 300). The coding procedures are

\footnotetext{
${ }^{8}$ For more about the identification of different types of perfect, see Gujord in press.
} 
available in Gujord $\left(2013,131-135^{9}\right)$, along with examples of coded interlanguage phrases. In addition, an inter-rater reliability test was conducted in order to ensure an acceptable level of coding. Another researcher coded $10 \%$ of the material, or 225 randomly selected verb phrases. The level of agreement was analysed by means of a Kappa analysis, which is a test for inter-rater reliability when the variables are categorical. The test statistics show that the overall level of inter-rater agreement is acceptable $($ Kappa $=0.7, \mathrm{p}<0.001) .{ }^{10}$

\subsubsection{Approach}

According to Bardovi-Harlig (2000, 252), two approaches to the analysis of lexical aspect can be distinguished: across-category analysis and within-category analysis. These two approaches differ in the emphasis they place on form: in an across-category analysis, which has been applied in the current study, the researcher pays most attention to morphological form, and investigates how a particular morpheme is distributed across the lexical-aspectual classes (Bardovi-Harlig 2000, 254). In a within-category analysis, more attention is given to lexical-aspectual categories, and the researcher investigates the morphological use within each category (Bardovi-Harlig 2000, 256). This is an important methodological distinction because the two approaches may yield different results when testing the predictions about the influence of lexical aspect on acquisition of temporal morphology (Bardovi-Harlig 2000, 252). Studies of the Aspect Hypothesis can also be distinguished by how forms are counted. Despite the fact that token counts are used in most studies of lexical-aspectual influence (Bardovi-Harlig 2000, 273), the present analysis of lexical aspect is concerned with type and not token. This is to prevent the results from being skewed and generating misinterpretations in cases where a category has a high frequency because a few words are used over and over again in the same text. For instance, $b e$ is a frequently used base word in interlanguages, which also often receives temporal marking early in the acquisition process; hence, it can potentially give the state category an artificially high frequency rate in analyses of lexical aspect if the analysis is based on token frequency (Collins 2002, 48). The number of distinct verb types marked for the preterite or the present perfect was counted and the proportion of verb types that occur inflected in telic or atelic verb phrases, or in any of the Vendlerian lexical-aspectual classes, was calculated. To illustrate, Figure 1 summarises the token counts and verb type counts generated by the analysis:

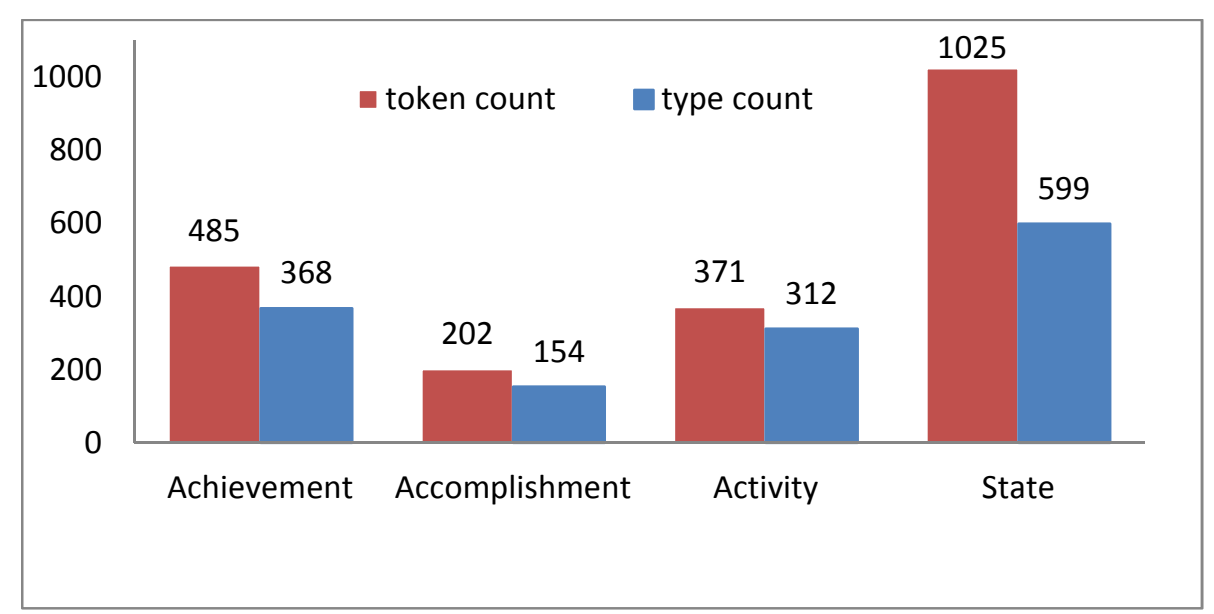

Figure 1. Token counts and type counts

\footnotetext{
${ }^{9}$ Downloadable: https://bora.uib.no/handle/1956/6867

${ }^{10}$ Kappa $>0.7$ is considered a "substantial” level of agreement according to Landis and Koch $(1977,165)$.
} 
As for the question of transfer, the approach taken in the current study is the comparison-based approach (Jarvis 2010). It relies on comparisons of the Norwegian interlanguage performances of two different L1 groups, comparisons of the encoding of time in three different language systems (Vietnamese, Somali, Norwegian), and comparisons of the grammatical encoding in the learners' Norwegian interlanguage performance with the system of their L1s (Vietnamese or Somali). Furthermore, the method for identifying L1 effects is line with Jarvis's (2000) methodological framework. ${ }^{11}$ In the present transfer analysis, the investigation of intra-L1-group homogeneity (criterion 1) and inter-L1-group heterogeneity (criterion 2) entails comparisons of the interlanguage performances of the Vietnamesespeaking learners and the Somali-speaking learners. Effects 1 and 2, intra-L1-group homogeneity and inter-L1 group heterogeneity were tested statistically by means of the Mann-Whitney U test. This test compares the group's internal behaviour to the differences in behaviour between the groups. Consequently, a significant result indicates that the observations within one group are sufficiently similar, and are sufficiently dissimilar from the observations in the other group, to establish that the groups behave in reliably different ways with respect to the measured variable. In the current study, intra-L1-group cross language congruity (criterion 3), is ensured by means of the translations of the perfect questionnaire by the native speakers of Vietnamese and Somali (see section 3).

\section{Findings}

5.1 Analysis of lexical-aspectual influence

The analyses in this section test one of the core predictions in the Aspect Hypothesis. According to this prediction, the proportion of sentences inflected, and also inflected correctly, for the past in verb phrases such as (13, coded as telic and achievement) and (14, coded as telic and accomplishment) will be significantly higher than the proportion inflections appearing in verb phrases such as (15, coded as atelic and activity) and (16, coded as atelic and state):

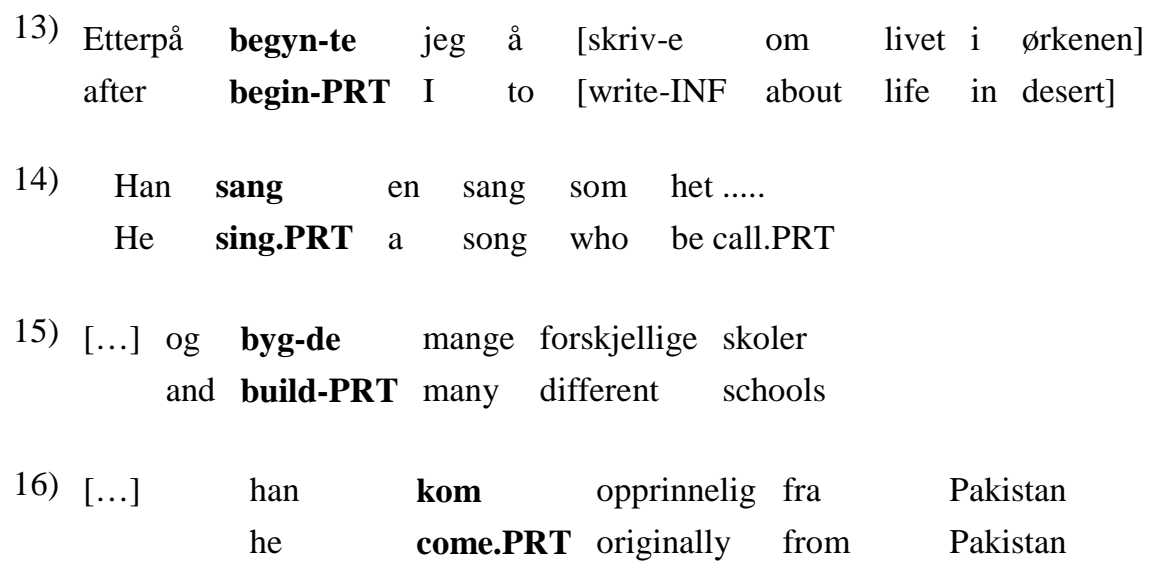

First, I analysed verb phrases coded as either telic and atelic (Section 5.1.1), both in overall use and correct use. Second, in Section 5.1.2 I analyse the proportion of verb types for all the

\footnotetext{
${ }^{11}$ Jarvis (2010) proposes a fourth type of evidence, intralingual contrast, which is not considered in the present study.
} 
four Vendlerian classes (illustrated in examples 13-16 above) Finally, the results of the analysis of lexical-aspectual influence will be summarised.

\subsubsection{Proportion of verb types in telic and atelic phrases}

Table 1 gives an overview of the data analysed for this section. The absolute frequencies for which verb types inflected for the past in telic and atelic verb phrases occur (as well as how many which occur correctly) are given on group level and on individual level. In the bottom row in Table 1 we see that the total number of verb types coded as either telic or atelic is 1433 , and that on average, each text contains 8.9 verb lexemes. We also know that 1300 types (8.1 lexemes) of these are used correctly. The main point of interest, however, is how these total 8.9 lexemes are distributed by telicity. Contrary to the predicted result, the large majority of them occur inflected for the past in atelic verb phrases (522 versus 911 , or 5.7 versus 3.2). Table 1 also presents information about individual variation inherent in the dataset, seen in the two columns on the right (minimum and maximum values, and number of texts without telic or atelic verb types).

Table 1. Verb types in telic and atelic phrases on group level and per individual text

\begin{tabular}{lrrrr}
\hline & group level & per individual text & min.-max. & no. of texts with zero occurrences \\
\hline & $\begin{array}{c}\text { no. of verb types } \\
\text { (correct/total) }\end{array}$ & $\begin{array}{c}\text { no. of verb types (mean) } \\
\text { (correct/total) }\end{array}$ & no. of occurrences & \\
telics & $475 / 522$ & $3.0 / 3.2$ & $0-15$ & 37 out of a total of 161 \\
atelics & $825 / 911$ & $5.1 / 5.7$ & $0-24$ & 4 out of a total of 161 \\
\hline total & $1300 / 1433$ & $8.1 / 8.9$ & & \\
\hline
\end{tabular}

Because the text length varies across the texts, the statistical analyses for the difference between the number of telic and atelic verb types expressed in Table 1 have to rely on proportions. Figure 2 graphically displays the percent proportion of verb types in telic and atelic verb phrases both in overall use and correct use. We see that the same trend in both analyses: on average $31.5 \%$ (mean) of all lexemes regardless of correctness are telic verb types and that $68.5 \%$ (mean) are classified as atelic verb types. The analysis of only correct verb phrases generates almost the exact same proportions (31.4 versus 68.6). This pattern is also evident in the number of texts without the feature being measured expressed in the right column in Table 1: the number of texts without telic verb types in Table 1 is much higher (37) than the number of texts without atelic verb types (4).

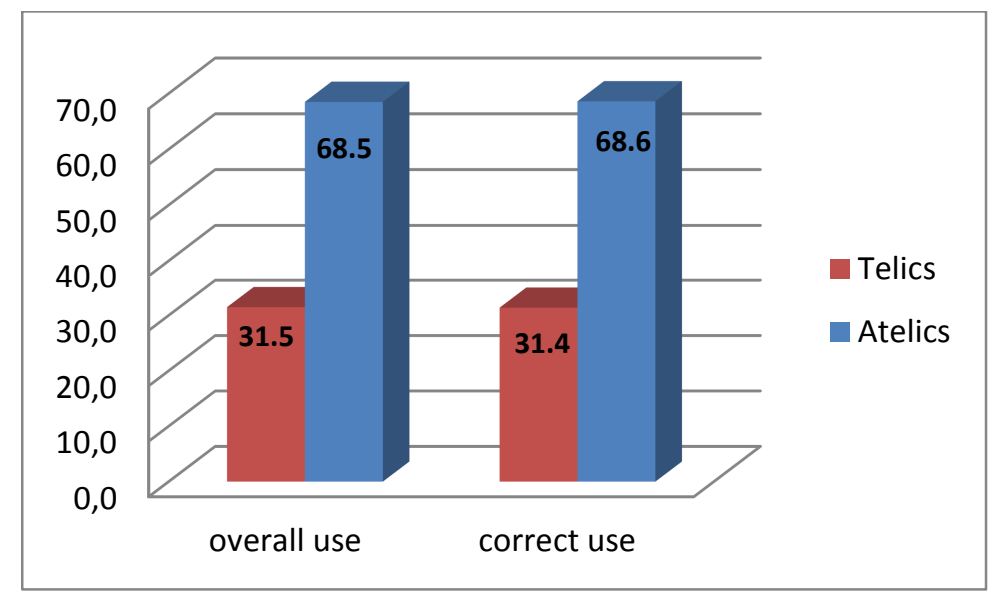

Figure 2. Percent proportion of verb types in telic and atelic phrases per individual text (mean) 
The difference in proportion is tested by means of the Wilcoxon signed rank test, a nonparametric test for assessing differences between dependent samples. The result shows that the difference in overall use is significant at a high alpha level $(\mathrm{z}=-7.998, \mathrm{p}<0.001)$ with a large effect size $(r=06)^{12}$. The difference in correct use is also significant at a high alpha level $(\mathrm{z}=-8.177, \mathrm{p}<0.001)$ with a medium effect size $(\mathrm{r}=0.6)$.

\subsubsection{Proportion of verb types in Vendlerian classes}

Table 2 gives an overview of the data analysed for this section: verb types in each of the Vendlerian classes. The figures in Table 2 indicate that the reason why atelic verb phrases are significantly more frequent occurrence of telic verb phrases discussed in Section 5.1.1 is that the state category occurs much more frequently than any of the other categories. In fact, 599 of the total 1433 lexemes are classified as states. Furthermore, the number of texts without states (19) is far lower than the number of texts which lack occurrences than any of the other categories $(46,50,82)$.

Table 2. Verb types in Vendlerian classes on group level and per individual text

\begin{tabular}{lcrrr}
\hline & group level & per individual text & min.-max. & $\begin{array}{c}\text { no. of texts with zero } \\
\text { occurrences }\end{array}$ \\
\hline & $\begin{array}{c}\text { no. of verb types } \\
\text { (correct/total) }\end{array}$ & $\begin{array}{c}\text { no. of verb types (mean) } \\
\text { (correct/total) }\end{array}$ & $\begin{array}{c}\text { no. of } \\
\text { occurrences }\end{array}$ \\
achievements & $338 / 368$ & $2.1 / 2.3$ & $0-10$ & 46 out of a total of 161 \\
accomplishments & $137 / 154$ & $0.8 / 1.0$ & $0-8$ & 82 out of a total of 161 \\
activity & $284 / 312$ & $1.8 / 1.9$ & $0-10$ & 50 out of a total of 161 \\
state & $541 / 599$ & $3.4 / 3.7$ & $0-18$ & 19 out of a total of 161 \\
\hline total & $1300 / 1433$ & $8.1 / 8.9$ & & \\
\hline
\end{tabular}

Figure 3 gives the proportions of verb types in the Vendlerian classes, and shows that the state category has a much higher proportion of verb types than any of the other categories both in overall use (45.8 versus $23.2,8.3,22.7)$ and correct use (46.4 versus $23.7,7.7,22.2)$ :

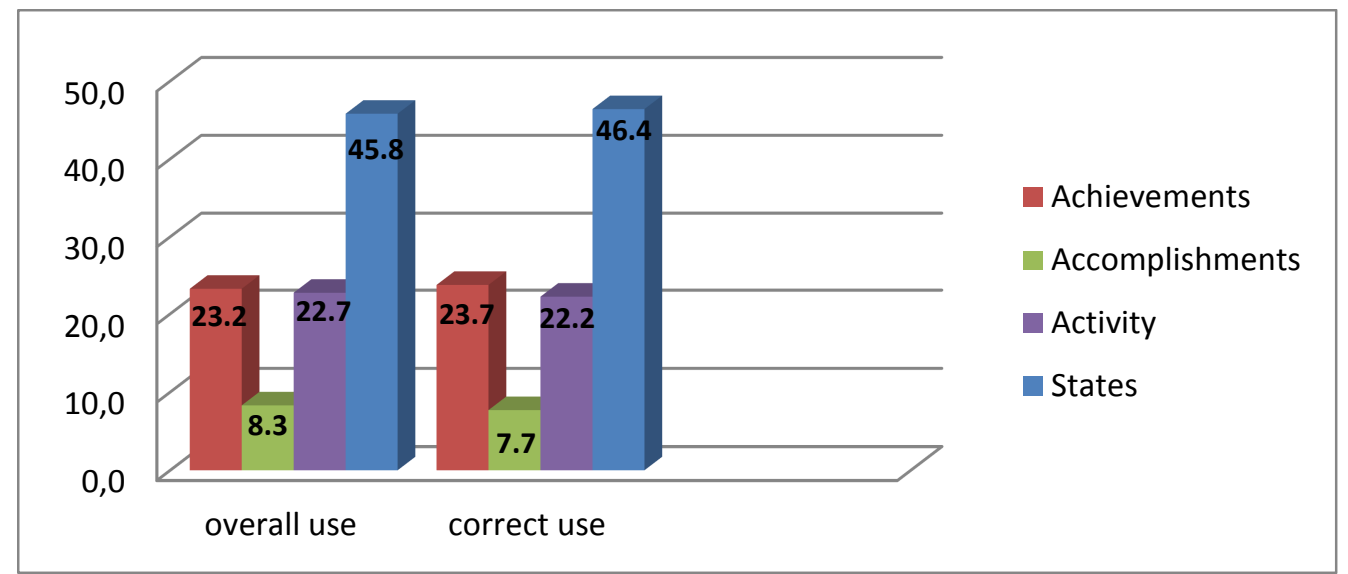

Figure 3. Proportion of verb types in Vendlerian classes per individual text (mean)

\footnotetext{
${ }^{12}$ The effect sizes for the Wilcoxon signed rank test, and the Mann-Whitney U test, are indicated by $r$, which is calculated from the $\mathrm{Z}$ statistics from the $\mathrm{U}$ test by dividing the $\mathrm{Z}$ statistics by the square root of $N$ (Larson-Hall $2010,377)$. For the chi-square test on a $2 \times 2$ table, I use Cramer's V as a measure of effect size (Larson-Hall 2010, 237).
} 
The statistical testing of the differences between the four Vendlerian classes has been carried out using the Friedman test, the non-parametric alternative to the Wilcoxon signed rank test when more than two dependent groups are compared. In order to locate the significant difference(s) when the Friedman test reports a significant result, separate Wilcoxon signed rank tests are used. ${ }^{13}$ The statistical analyses of overall use show that the state and the accomplishment categories differ significantly from all the other categories: the state category has a significantly higher proportion of verb types than the rest of the categories (state activities: $\mathrm{z}=-7.764, \mathrm{p}<0.001, \mathrm{r}=0.6$, state - accomplishments, $\mathrm{z}=-9.934, \mathrm{p}<0.001, \mathrm{r}=$ 0.8 , state - achievements: $\mathrm{z}=-6.403, \mathrm{p}<0.001, \mathrm{r}=0.5$ ). The accomplishment category has a significantly lower proportion of verb types than the rest of the categories (accomplishment states: $\mathrm{z}=-9.934, \mathrm{p}<0.001, \mathrm{r}=0.5$, accomplishments - activities, $\mathrm{z}=-6.625, \mathrm{p}<0.001, \mathrm{r}=$ 0.5 , accomplishments - achievements: $\mathrm{z}=-7.606, \mathrm{p}<0.001, \mathrm{r}=0.6$ ). Achievements and activities do not differ significantly from each other in proportions of verb types. As for the proportions of correct phrases, post hoc testing reveals that the state category has a significantly higher proportion of verb types than the rest of the categories (state - activities: $\mathrm{z}$ $=-6.188, \mathrm{p}<0.001, \mathrm{r}=0.5$, state - accomplishments, $\mathrm{z}=-9.527, \mathrm{p}<0.001, \mathrm{r}=0.8$, state achievements: $\mathrm{z}=-6.061, \mathrm{p}<0.001, \mathrm{r}=0.5)$.

\subsubsection{Summary of findings from the analysis of lexical-aspectual differences}

The prediction of the Aspect Hypothesis for L2 acquisition of past morphology is not supported. The prediction was that the encoding of past time would appear more often, and more often correctly, in telic verb phrases, and furthermore, that the use of morphology expands from achievement - accomplishment - activity - state. This prediction is not supported since atelic verb phrases with past morphology have a significantly higher proportion of verb types than telic verb phrases with past morphology in overall use as well in correct use. Furthermore, it is the state category that differs significantly from the other classes of lexical aspect, and which contributes to the fact that atelic verb phrases have a significantly higher proportion of verb types inflected for the past.

5.2 L1 influence: Results of the analysis of the uses of the present perfect and the preterite The testing of the hypothesis related to L1 influence includes analyses of the correct uses of the present perfect and the preterite separately, and an analysis of the incorrect uses of these two forms in place of each other. Note that the number of texts $(N)$ changes in the tables in this section. This is because the types of temporal contexts included in the altogether 161 texts (73 Vietnamese and 88 Somali texts) vary quite a bit, and some contexts, for instance perfect contexts, are not that frequent and several texts do not have this type context at all. For instance, from the row at the right end in Table 3 below, the total number of Vietnamese texts is not 73 for the analysis of the correct uses of present perfect, but 53, because 20 texts do not have present perfect contexts.

\subsubsection{Analysis of correct use}

Table 3 and Table 4 report the figures used in the analysis of correct use of the preterite and present perfect in obligatory contexts. For instance, from Table 3 we know that there are 79 of 94 contexts in which the present perfect in the Vietnamese material is used correctly, and that the same number is 99 out of a total of 141 in the Somali material. From table 4 we see that the frequency of preterite contexts (and correct use) is much higher than of present perfect (in

\footnotetext{
${ }^{13}$ At this step, the Bonferroni correction is applied so as to avoid falsely claiming that significant differences exist, which is a risk when performing multiple pairwise tests.
} 
Table 3). This difference is also clear if we compare the minimum and maximum values in Table 3 and Table 4. The figures on individual level indicate, for instance, that the Vietnamese learners seem to code both types of past contexts more often correctly than Somali learners.

Table 3. Correct uses of the present perfect on group level and per individual text by L1

\begin{tabular}{lrrrr}
\hline & group level & per individual text & min. - max. & $\begin{array}{c}\text { no. of texts with only } \\
\text { correct uses }\end{array}$ \\
\hline & no. of correct uses by & no. of correct uses by & no. of correct & \\
& context (correct/context) & context (correct/context) & occurrences & \\
Vietnamese & $79 / 94$ & $1.5 / 1.8$ & $0-5$ & 40 out of a total of 53 \\
Somali & $99 / 141$ & $1.5 / 2.1$ & $0-6$ & 42 out of a total of 66 \\
\hline total & $178 / 235$ & & & \\
\hline
\end{tabular}

Table 4. Correct uses of preterite on group level and per individual text by L1

\begin{tabular}{lrrrr}
\hline & group level & per individual text & min.-max. & $\begin{array}{c}\text { no. of texts with only } \\
\text { correct uses }\end{array}$ \\
\hline & $\begin{array}{c}\text { no. of correct uses by } \\
\text { context (correct/context) }\end{array}$ & $\begin{array}{c}\text { no. of correct uses by } \\
\text { context (correct/context) }\end{array}$ & $\begin{array}{c}\text { no. of } \\
\text { correct } \\
\text { occurrences }\end{array}$ \\
Vietnamese & & \multicolumn{3}{c}{ of of total of 63} \\
Somali & $770 / 854$ & $12.2 / 13.6$ & $0-42$ & 32 out of a total of 71 \\
\hline total & $942 / 1080$ & $13.3 / 15.2$ & $0-44$ & 24 out of a \\
\hline
\end{tabular}

In order to analyse the difference in correct use between the L1 groups statistically, I have calculated the percent proportion of correct use of the present perfect and preterite. The proportions are displayed in Figure 4:

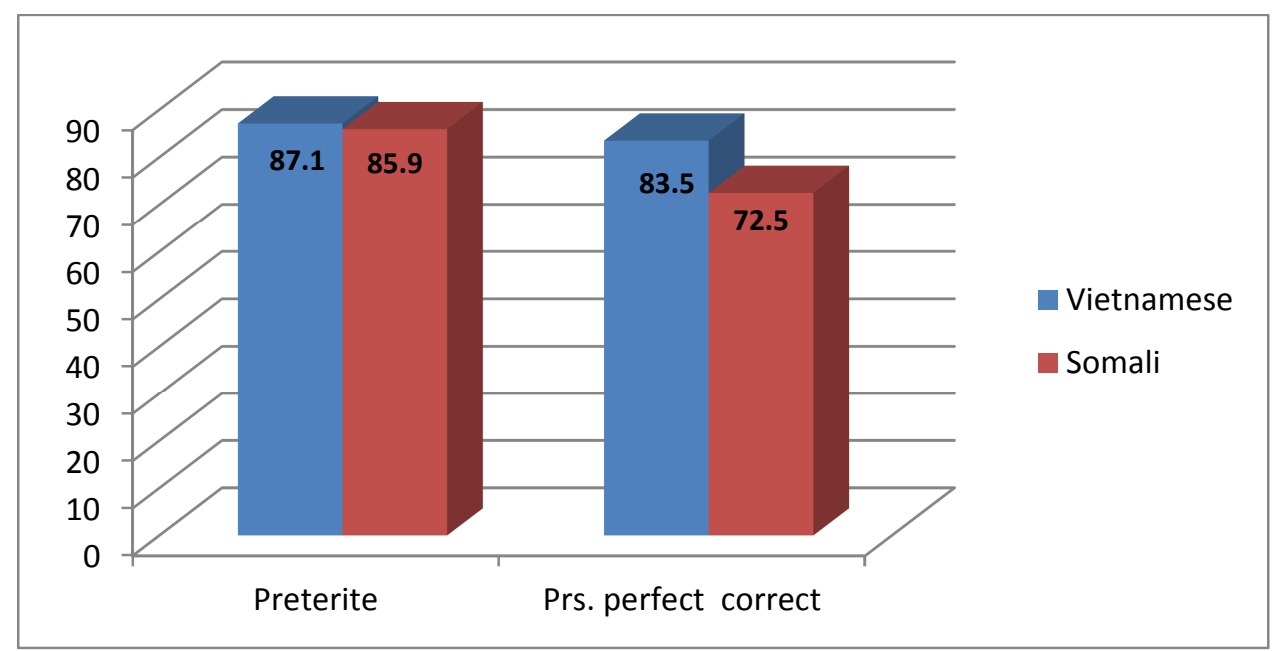

Figure 4. Percent proportion of correct use of perfect and preterite by LI

From Figure 4 we see that whereas the percentage of correct uses of the preterite is rather similar (87.1 and 85.9), there is a notable difference in correct uses of the present perfect in the predicted direction: the largest proportion is found in the Vietnamese group (83.5 versus 72.5). From the right column in Table 3, we know that the proportion of texts with $100 \%$ correct use of the present perfect is higher in the Vietnamese group (40 out of 53) than in the Somali group (42 out of 66). However, a one-tailed Mann Whitney $U$ test finds that this difference is not significant $(\mathrm{U}=1514.5, \mathrm{z}=-1.533, \mathrm{p}=0.1)$ and that the effect size is small 
$(\mathrm{r}=0.1)$. Also, the difference between the proportion of correct uses in preterite contexts is insignificant $(\mathrm{U}=1904.5, \mathrm{z}=-1.537, \mathrm{p}=0.1$, small effect size, $\mathrm{r}=0.1)$.

\subsubsection{Analysis of incorrect use}

This part of the analysis concerns those texts with clauses in which a preterite form occurs inappropriately in a present perfect context, and/or clauses in which a present perfect form occurs inappropriately in a preterite context. Table 5 and Table 6 present the absolute frequencies on group level and individual level for the two types of error distribution:

Table 5. Preterite incorrectly used in a present perfect context by L1

\begin{tabular}{lcrrr}
\hline & group level & per individual text & min.-max. & $\begin{array}{c}\text { no. of texts with zero } \\
\text { incorrect uses }\end{array}$ \\
\hline & no. of incorrect uses & no. of incorrect uses & no. of incorrect & \\
(incorrect/total use) & (incorrect/total use) & occurrences & \\
Vietnamese & $3 / 841$ & $0.04 / 12.5$ & $0-1$ & 64 out of a total of 67 \\
Somali & $36 / 1019$ & $0.5 / 13.2$ & $0-4$ & 58 out of a total of 77 \\
\hline total & $39 / 1860$ & & & \\
\hline
\end{tabular}

Table 6. Present perfect incorrectly used in a preterite context by $\mathrm{LI}$

\begin{tabular}{lrrrr}
\hline & group level & per individual text & min. - max. & \multicolumn{1}{c}{$\begin{array}{c}\text { no. of texts with zero } \\
\text { incorrect uses }\end{array}$} \\
\hline & no. of incorrect uses & no. of incorrect uses & no. of incorrect \\
(incorrect/total use) & (incorrect/total use) & occurrences & \\
Vietnamese & $6 / 96$ & $0.1 / 1.9$ & $0-2$ & 46 out of a total of 51 \\
Somali & $17 / 127$ & $0.2 / 2.2$ & $0-3$ & 45 out of a total of 58 \\
\hline total & $23 / 223$ & & & \\
\hline
\end{tabular}

One should be cautious when interpreting the tendencies expressed numerically in Table 5 and Table 6 due to the great variation in frequency of incorrect use of both types and because the frequencies are based on small figures, particularly when reading Table 6 , which presents the incorrect uses of the perfect in preterite contexts. Still, the absolute frequencies displayed in Table 5 and Table 6 indicate a systematic difference between the two L1 groups in error distribution, for instance, the incorrect use of the preterite in perfect contexts appears mainly in Somali texts (Table 5): this type of error is found in only 3 Vietnamese texts (64 of 67 texts have no occurrences), but is found in 19 Somali texts. In Figure 5, displaying the percent proportion of preterite and perfect forms incorrectly used in place of each other, this trend is easily inferred through the large differences in length between the bars representing the proportions in the L1 groups. 


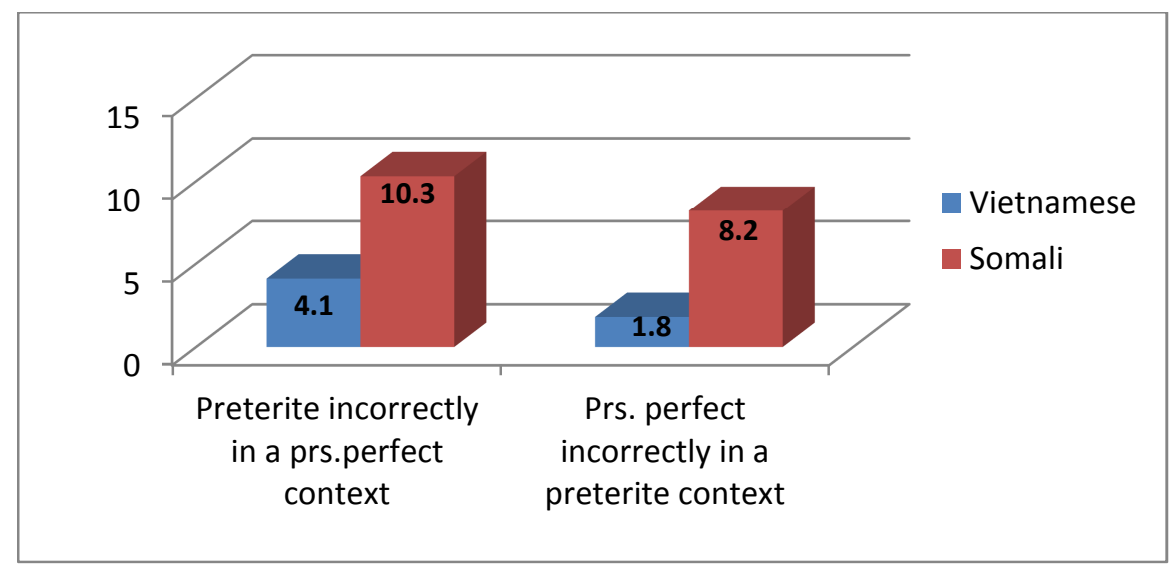

Figure 5. Percent proportion of preterite and perfect forms incorrectly used in place of each other by L1

A one-tailed Mann Whitney $U$ test reports that the difference in proportion incorrect use of the preterite in perfect contexts is significant $(\mathrm{U}=2066.0, \mathrm{z}=-3.285, \mathrm{p}=0.0005)$ and the effect size is medium $(r=0.3)$. Because more than $30 \%$ of the texts obtain a $0 \%$ score (lack of occurrences of this type of error) a post hoc chi square test was performed in order to find out if the overall significance revealed in the initial testing is due to a significant difference between the groups in the proportion of texts having a 100\% value or a $0 \%$ value for the quality measured. The chi square test showed that there was a significantly higher proportion of Somali texts with this particular incorrect distribution $\left(\chi^{2}=11.291, p=0.001\right)$ compared to Vietnamese texts, and that the effect size of this difference is medium (Cramer's $V=0.3$ ).

The proportion of perfect forms occurring incorrectly in contexts for the preterite is also higher in the Somali group. This difference was tested for significance by means of the same stepwise approach, which produced a significant result $(\mathrm{U}=1292.5, \mathrm{z}=-1.752, \mathrm{p}=0.04$ with a small effect size, $r=0.2$ ). A post hoc chi square test showed that a significantly higher proportion of Somali texts than Vietnamese texts have incorrect distribution of the present perfect in preterite contexts $\left(\chi^{2}=3.130, p=0.04\right)$, and that the size of this effect is small (Cramer's V $=0.2$ ).

Figure 6 illustrates this statistically significant pattern of incorrect encoding. The bars represent individual texts, and the $\mathrm{x}$-axis refers to the number of misuses of the present perfect and the preterite in place of each other per text. Clearly, this type of error characterises the encoding of past time in Somali texts. The red bars, representing Somali texts, dominate (31 out of total 39 texts):

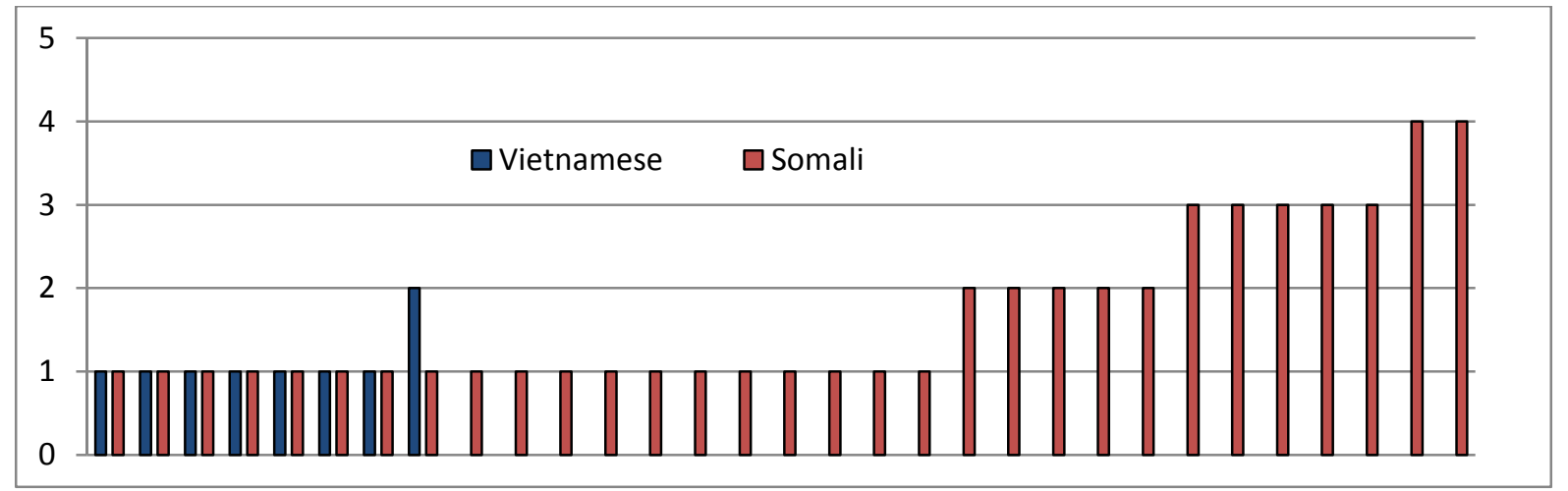

Figure 6. Texts with incorrect uses of the preterite and the present perfect in place of each other by LI 


\subsubsection{Summing up findings from the analysis of L1 differences}

The analysis of L1 influence tested a hypothesis predicting specific transfer effects to emerge in the uses of the present perfect and the preterite. Although the Vietnamese learners do not use the perfect more correctly than the Somali learners do, a systematic difference between the L1 groups is detected in the distributional pattern of the preterite and the present perfect: Somali-speaking learners use the preterite and the present perfect incorrectly because they confuse the two forms more often than Vietnamese-speaking learners do. In particular, the Somali-speaking learners' overuse of the preterite in Norwegian is solidly documented. Accordingly, incorrect sentences, such as examples 17-20 taken from the data set, are characteristic of the Norwegian interlanguages of Somali learners and not of the interlanguages of Vietnamese learners. The incorrect verb clauses are bolded.

17) Jeg ha-r flytt-et mange ganger da jeg bo-dde i PLACE I have-PRS AUX move- PST PTCP several times when I live-PRT in PLACE

18) Da jeg var i PLACE ha-r jeg røyk-et i nesten to år when $\mathrm{I}$ be. PRT in PLACE have-PRS AUX I smoke-PST PTCP in almost two year

19) Jeg tenk-te meg å bli sykepleier siden jeg var barn I think.PRT me to become nurse since I be. PRT child

20) Jeg jobb-et hardt hele livet mitt att framtida min ... I work.PRT hard whole life mine so future mine ...

\section{Summary and discussion of findings}

There are two important findings in this study. First, this study provides further empirical support for the existence of a particular L1-specific pattern that has previously been observed in several studies concerning the acquisition of past morphology in L2 English and L2 Norwegian. The present perfect category poses challenges when L2 learners are not familiar with the category from their L1 or when there are formal or conceptual differences or similarities between a tense-aspect category in the L1 and the perfect category in the L2. Second, this study fails to support one of the core predictions of the Aspect Hypothesis specifically that telic verb phrases will be inflected for the past before atelic verb phrases. The "negative" evidence uncovered here is important because the influence of lexical aspect has hitherto been viewed as universal within the Aspect Hypothesis framework.

It is my opinion that the present study of the Aspect Hypothesis thus highlights the importance of using different types of data to test the hypothesis. I have used a type of data that is not typically used in Aspect Hypothesis research. Bardovi-Harlig (2000, 197-205) surveys data type and approaches in Aspect Hypothesis research, and even though her survey shows quite a lot of diversity, studies investigating written language use data produced in a test situation, such as in the present study, do not seem to be a part of the empirical base Bardovi-Harlig reviews. Written narratives are used as data, however, the written data are typically collected by means of various retell tasks, e.g. film retells, in order to provide comparable data samples (Bardovi-Harlig 2000, 201). Hence, the texts analysed in the studies reviewed by Bardovi-Harlig are often written as responses to the same task, or as responses to 
the same stimuli. This is not the case in the present study, where the texts investigated were free narratives written in response to various prompts given at language test. The fact that the Aspect Hypothesis is not corroborated when tested with another type of data than that has been commonly used, indicates that the type of data used in the predictions should be expanded to other types of data as well, such as corpus data, or even better, data elicited in various types of environments. This was done in a recent study by Domínguez et al. (2013) of Spanish L2 learners' acquisition of past morphology, which elicited data from different oral tasks that differed in the degree of control in the environment. This study clearly shows that the type of data influences the results when testing the Aspect Hypothesis. Although the learners followed the predictions of the Aspect Hypothesis in the task type closest to the data commonly exploited in this type of research (free narrative tasks, e.g. interviews and retellings), the very same learners did not produce a pattern that confirmed the hypothesis when they were given the task of telling a story based on a series of pictures. The motivation for including a controlled task type was to ensure that the learners had to inflect verbs in nonprototypical contexts and not only in prototypical contexts. According to Domínguez et al. (2013, 562), the data elicited through the type of narratives that Aspect Hypothesis research usually relies on, are characterised by the associations that the Aspect Hypothesis predicts. This is a methodological problem in the research because such contexts "are often unsuccessful at providing full and convincing evidence about the L2 development of past tense form-to-meaning associations" (Domínguez et al. 2013, 562).

However, although both the Domínguez et al. study and the present one suggest that effects of contexts in which the data are elicited should be further explored in research on the Aspect Hypothesis, the weaknesses of relying on only one type of data, as done in the present study, must also be mentioned. The fact that I did not have the opportunity to influence the topics written about, and consequently could not ensure a certain amount of lexical diversity, probably complicated the testing of effects of telicity. From the analysis of lexical-aspectual influence it is also clear that even though the use of past morphology in the texts was analysed by means of a verb type analysis and not a token analysis (meaning that this result should be reliable in the sense that lexical diversity is controlled for), the state category obtains significantly higher proportions of verb type. However, a closer look into the data reveals that even though a verb type analysis takes lexical variation into consideration because each inflected verb is only counted once, in many cases, the verb type counted is 'være' ('be'). In fact, 113 out of 157 texts with stative tokens (or $72 \%$ of the texts) have on average 4.3 uses of 'være' in their texts. In comparison, the most frequent verb appearing in the achievement category, 'bli' ('become') is found in 43 out of 138 texts with telic tokens (or $31 \%$ of the texts), which gives an average use of 1.9. In other words, the type analysis in the current study does not rule out the overrepresentation of 'være' because it appears in so many texts and because the other verbs occur in far fewer texts. However, even though there are methodological matters that might help explain why the findings in the present study are inconsistent with previous findings, there is more to it than simply a matter of potentially "inappropriate" data. Both Domínguez et al. study and the present one demonstrate that method and approach matter when testing the Aspect Hypothesis. Hence, such findings lay a 
foundation for questioning the rather strong formulation of the Aspect Hypothesis, as well as for questioning the literature surveying this line of research that identifies lexical-aspectual influence as "the" factor in the acquisition of temporal morphology. As demonstrated in Domínguez et al. (2013), under certain conditions learners are able to make untypical associations between the semantics of the inflectional morphology and the semantics of the verb that is inflected.

One of the factors that also plays a role in L2 acquisition of temporality is L1 influence. In the present study, the detected L1 effects are primarily a matter of tense-marking errors. The L1 difference in the encoding of past time revealed in the present study is not necessarily so much about correctness, but rather constitutes a difference in distributional patterns that emerge as a particular type of incorrect encoding: the Somali learners, whose L1 does not code the distinctions encoded in the present perfect, have more problems distinguishing the preterite from the present perfect form than the Vietnamese learners do. The clearest proof of this is the high frequency of incorrect use of the preterite in present perfect contexts. This result aligns with previous findings presented in Section 2, that the present perfect category poses challenges when L2 learners are not familiar with the category from their L1, or when there are formal or semantic differences or similarities between a tense/aspect category in the L1 and the perfect category in the L2. These are important findings because, as cited in the introduction, Bardovi-Harlig (2000) did not find strong evidence for claiming the $\mathrm{L} 1$ to be an important variable in the L2 acquisition of temporality.

The fact that transfer effects are detected, and effects of verb semantics as described in one of the predictions of the Aspect Hypothesis is not detected, is not in itself evidence against the Aspect Hypothesis. In other words, telicity most likely has a role to play; however, the present study does demonstrate that in different circumstances, other factors, such as L1 influence might override, conceal, or conflate its influence.

\section{Limitations of the study and conclusion}

The present analyses yield information about the encoding of time in the texts on several levels, including the level of inflection and the level of semantics. However, the broad scope of the study is also one of its limitations because of the lack of a more detailed and closer look into particular issues that could have been beneficial. For instance, an issue which has not been dealt with in this article is the complexity of the present perfect category. The perfect category tends to develop rapidly in languages, and typically serves different functions within and across languages. A more in-depth examination of the encoding of the different types of perfect contexts would therefore be beneficial both for the analysis of lexical-aspectual influence and for the analysis of L1 influence (see also Gujord [in press], where this is elaborated). Regarding limitations of the data set, this type of language data was biased towards the use of one specific verb lexeme, 'være' ('be'), which always occurred in atelic phrases. Hence, an additional data set of a different kind, preferably produced in a more controlled research environment, could have also increased the lexical diversity and ensured a sufficient number of types from each lexical-aspectual class, which could have been studied in comparison to the corpus data. Finally, there are also limitations of the statistical method applied in the current study. Although the data have been analysed by means of a systematic statistical approach, I have not used a statistical method that can capture and analyse the interaction between the factors. The method adopted here is simplistic in the sense that it only 
analyses one factor at a time because the effects of L1 influence and lexical-aspectual influence have been analysed separately. Clearly, multivariate statistical techniques would have been advantageous for the analysis, and could also make possible to investigate another issue of importance: how these two sources of influence (verb semantics and L1) may interact (see also Collins 2002, 2004; Ayoun and Salaberry 2008; Gujord 2013, 310-318). Despite its limitations, the current study does shed light on central research questions in SLA which concern the role of universal and language-specific factors in L2 acquisition. The study offers insight into the relativity of the Aspect Hypothesis based on learner corpus data, and adds further support about the importance of L1 specific patterns in the acquisition process.

\section{References}

Andersen, R. 1991. Developmental sequences: the ermergence of aspect marking in second language acquisition. In Crosscurrents in second language acquisition and linguistic theories, eds. T. Huebner and C. A. Ferguson, 305-324. Amsterdam: John Benjamins.

Andersen, R. and Shirai, Y. 1994. Discourse motivations for some cognitive acquisition principles. Studies in second language acquisition 16, 133-156.

Ayoun, D. and Salaberry, R. M. 2008. Acquisition and English tense-aspect morphology by advanced French instructed learners. Language Learning 58 (3), 555-595.

Bardovi-Harlig, K. 2000. Tense and aspect in language acquistion: Form, meaning and use. Language Learning, 50 (Supplement 1), xi-491.

Carlsen, C. 2012. Proficiency level - a fuzzy variable in computer learner corpora. Applied Linguistics, 33 (1), 1-24.

Chan, H. L., Finberg J., Costello, W. and Shirai, Y. 2012. L2 acquisition of tense-aspect morphology. In Space and time in languages and cultures, eds. Luna Filipović and Katarzyna M. Jaszczolt, 181-204. Amsterdam: J. Benjamins.

Collins, L. 2002. The Role of L1 Influence and Lexical Aspect in the Acquistion of Temporal Morphology. Language Learning 52 (1), 43-94.

Collins, L. 2004. The Particulars on Universals: A comparison of the acquisition of tenseaspect morphology among Japanese and French-speaking learners of English. Canadian Modern Language Review 61, 251-274.

Comrie, B. 1976. Aspect: An introduction to the study of verbal aspect and related problems. Cambridge: Cambridge University Press.

Comrie, B. 1985. Tense. Cambridge: Cambridge University Press.

Dahl, Ö. 1985. Tense and aspect systems. Oxford: Blackwell.

Dietrich, R., Klein W. and Noyau, N. 1995. The acquisition of temporality in a second language. Amsterdam: J. Benjamins.

Domínguez, L., Tracy-Ventura, N., Arche, M. J., Mitchell, R. and Myles, F. 2013. The role of dynamic contrasts in the L2 acquisition of Spanish tense morphology. Bilingualism: Language and Cognition 16 (3), 558-577.

Gujord, A.K.H. 2013. Grammatical encoding of past time in L2 Norwegian. The roles of L1 influence and verb semantics. PhD Thesis. Faculty of Humanities, University of Bergen. (https://bora.uib.no/handle/1956/6867)

Gujord, A.K H. in press. The "perfect candidate" for transfer. A discussion of L1 influence in L2 acquisition of tense-aspect morphology. Forthcoming in Jarvis, Tenfjord, and Golden (eds.).

Hagen, J. E. 1998. Norsk grammatikk for andrespråkslaerere. Oslo: Ad Notam Gyldendal. 
Helland, A. K. 2005. I møte med eit tempusprominent språk: ei undersøking av mellomspråka til vietnamesiske norskinnlærarar. Unpublished Master's thesis. Faculty of Humanities, University of Bergen.

Izquierdo, J. and Collins, L. 2008. The facilitative role og L1 influence in tense-aspect marking: A comparison of Hispanophone and Anglophone learners of French. The Modern Language Journal 92, 350-368.

Janik, M. O. 2010. En polakk i norsk fortid. Om feil de polskspråklige norskinnlærerne gjør i bruk av perfektum og preteritum. Folia Scandinavia 1, 87-100.

Jarvis, S. 2000. Methodological Rigor in the Study of Transfer: Identifying L1 Influence in the Interlanguage Lexicon. Language Learning 50 (2), 245-309.

Jarvis, S. 2010. Comparison-based and detection-based approaches to transfer reasearch. In L. Roberts, M. Howard, , M. Ó Laoire and D. Singleton (Eds.). EUROSLA Yearbook. Amsterdam: John Benjamins Publishing Company, 169-192.

Jarvis, S. and Odlin, T. 2000. Morphological type, spatial reference, and language transfer. Studies in second language acquisition 22, 535-556.

Jarvis, S. and Pavlenko, A. 2008. Crosslinguistic influence in language and cognition. New York: Routledge.

Karrer, I. U. 1999. Falske venner?: en studie av preteritums- og perfektumsformene i tyske språkinnlæreres norske mellomspråk. Unpublished Master's thesis. Faculty of Humanities, University of Bergen.

Landis, R. and Koch, G. G. 1977. The measurement of observer agreement for categorial data. Biometrics 33 (1), 159-174.

Larson-Hall, J. 2010. A guide to doing statistics in second language research using SPSS. New York: Routledge.

Lindstedt, J. 2000. The perfect - aspectual, temporal and evidential. In Tense and Aspect in the Languages, ed. Östen Dahl, 366-383. Berling: Mouton de Gruyter.

Moskvil, M. E. 2004. Temporalitet i morsmål, målspråk og mellomspråk, Unpublished M.A. thesis. Faculty of Humanities, University of Bergen.

Odlin, T. 2005. Crosslinguistic influence and conceptual transfer: What are the concepts? Language Learning 25, 3-25.

Ortega, L. 2009. Understanding second language acquisition. London: Hodder Education.

Polunenko, A. 2004. English past tense forms in Russian's speakers oral and written production. Unpublished Master's thesis. Department of Linguistics, Ohio University.

Randen, G. T. 1999. Aspektualitet: en sammenlignende studie av norsk, russisk og russiske informanters norske mellomspråk. Unpublished Master's thesis. Faculty of Humanities, University of Bergen.

Saeed, J. I. 1993. Somali reference grammar. Kensington, Md.: Dunwoody Press.

Sharma, D. and Deo. A. 2009. Contact-based aspectual restructuring: A critique of the Aspect Hypothesis. Occasional Papers Advancing Linguistics, Queen Mary's OPALs, 1-29.

Shirai, Y. 2009. Temporality in first and second language acquisition. In The expression of time, eds. Wolfgang Klein and Ping Li, 167-193. Berlin: Walter de Gruyter.

Shirai, Y. 2013. "Defining and coding data: Lexical aspect in L2 studies. In R. M. Salaberry and L. Comajoan, Research design and methodology in studies on L2 tense and aspect. Boston: de Gruyter Mouton, 271-308.

Tenfjord, K. 1997. ^̊ ha en fortid på vietnamesisk: en kasusstudie av fire vietnamesiske språkinnlæreres utvikling av grammatisk fortidsreferanse og perfektum. Unpublished doctoral dissertation. Faculty of Humanities, University of Bergen. 
Gujord

Tenfjord, K., Meurer, P. and Hofland, K. 2006. The ASK Corpus-a Language Learner Corpus of Norwegian as a Second Language. Abstract at Proceedings from 5th International Conference on Language Resources and Evaluation (LREC), at Genova, 1821-1824.

Thompson, L. C. 1965. A Vietnamese grammar. Seattle: University of Washington Press.

Vendler, Z. 1967. Linguistics in philosophy. Ithaca, N.Y.: Cornell University Press. Original edition.

\section{Corpora}

ASK, see http://clarino.uib.no/ask/ask

\section{Appendix}

List of abbreviations

$\begin{array}{ll}\text { ADV } & \text { adverb(ial) } \\ \text { AUX } & \text { auxiliary } \\ \text { DM } & \text { declarative marker } \\ \text { INF } & \text { infinitive } \\ \text { PRS } & \text { present } \\ \text { PST } & \text { past } \\ \text { PTCP } & \text { participle } \\ \text { PRT } & \text { preterite } \\ \text { PST SIMPLE } & \text { past simple } \\ \text { TM } & \text { time marker }\end{array}$

